\title{
ON THE INHERITANCE OF ACQUIRED ANTIBODIES.
}

\author{
By J. R. LEARMONTH, M.B., Сн.B., \\ Extra Dispensary Surgeon, Western Infirmary, Glasgow. \\ (From the Physiological Institute ${ }^{1}$, University of Glasgow.)
}

THE presence of antibodies in the body fluids of the offspring of immunised parents has long been studied and variously explained. In 1912, Famulener ${ }^{2}$ published a clear summary of the work upon the subject up to that date. Renewed interest in the problem has been aroused by the work of the Department of Animal Pathology of the Rockefeller Institute for Medical Research, where the transmission of immunity to the Bacillus abortus is being studied. It has been shown by Little and Orcutt ${ }^{3}$ that agglutinins for this bacillus are transferred exclusively by the colostrum, since a calf from which colostrum is withheld does not show this agglutinin in its serum, although a high titre of agglutinin may be demonstrable in both serum and colostrum of the dam. Later Orcutt and Howe ${ }^{4}$, using a method of separating the protein fractions of serum devised by the latter ${ }^{5,6}$, showed that the appearance of agglutinins in the serum of a calf fed with colostrum of high agglutinin titre was closely related to the appearance of euglobulin, which is absent from the blood of the newly born calf. Further, Smith and Little ${ }^{7}$ showed that this absorption of agglutinin from the digestive tract also occurred when the calf was fed with serum rich in that antibody. The association of agglutinin with the globulin fraction of serum, and in particular with the euglobulin fraction, has been demonstrated by Orcutt and Howe 4 , who found that "the agglutinins are associated with the protein fractions which are precipitated up to and including 16.4 per cent. of sodium sulphate," and that "a large proportion of the agglutinins is associated with the fraction which is precipitated by $14 \cdot 2$ per cent. of sodium sulphate, euglobulin." Again, although a milk might show a high titre of agglutinin, with no corresponding increase in the proportion of its globulin, yet the agglutinin was removed from the milk by a concentration of sodium sulphate which removed the globulin fraction of the protein. In support of the direct absorption of protein from the digestive tract these

\footnotetext{
1 This work was made possible by a grant from the Medical Research Council, to whom my best thanks are due.

2 Famulener, L. W. (1912). Journ. Infect. Dis. x. 332.

3 Little, R. B. and Orcutt, M. L. (1922). Journ. Exp. Med. xxxv. 161.

4 Orcutt, M. L. and Howe, P. E. (1922). Ibid. Xxxvi. 291.

5 Howe, P. E. (1921). Journ. Biol. Chem. xuIx. 93.

6 Ibid. XLIX. 115.

7 Smith, T. and Little, R. B. (1923). Journ. Exper. Med. xxxvir. 671.
} 
authors quote the work of Langer ${ }^{1}$, who prepared an antiserum to colostrum; using the precipitin test, he was unable to find substances in the blood of the new-born calf which would react with colostrum antiserum, whereas colostrum antiserum and cow blood did react. After suckling, and as early as six hours after suckling, substances appeared in the blood of the calf which reacted with colostrum antiserum. Raymann ${ }^{2}$, whose work was done on goats, added evidence for the transmission of antibodies by the colostrum, by observing the serum content of normal agglutinin in the blood of kids before and after the ingestion of colostrum; he found that this body was transmitted to the kid in the colostrum of the mother, but that no quantitative rule was demonstrable.

More recently Lewis and Wells ${ }^{3}$ have extended the inquiry to man and find that new-born infants have little or no euglobulin in their blood; that euglobulins gradually appear; and that their amount is increased by the early ingestion of colostrum. Since it seems clearly established, at least in the case of animals whose young depend for their early nutrition upon the mother, that any existing maternal immunity for certain diseases is transmitted in association with the globulin fraction of the colostrum, it would be theoretically possible to increase this immunity by the administration to the infant of heterologous serum or colostrum of high titre in antibody for the particular disease. Lewis and Wells, however, sound a warning against such a practice, and point out that such protection "would be passive and therefore transient, while the sensitization would be active and permanent," and might lead to dangerous hypersensitivity in adult life.

The experimental work reported in this paper was done on the guineapig, whose young are little dependent on the female for their early food supply. It differs from the work quoted above in the use of the B. typhosus to create immunity in the parents, as opposed to the $B$. abortus which occurs naturally in the cow.

Method. The animals were actively immunised by the injection of regulated doses of the Standard Agglutinable Culture of B. typhosus prepared by the Standards Laboratory, University of Oxford.

Weekly doses of from 0.50 c.c. to 1.50 c.c. of the culture were given intraperitoneally, except in the case of females advanced in pregnancy, when they were subcutaneous; since it was found that the former method might induce abortion. The agglutinating power of the serum was determined with this culture according to Dreyer's ${ }^{4}$ procedure, blood being obtained from the marginal vein of the ear. The results are given in the form of the content of sera in arbitrary "Standard Agglutinin Units" (s.A.U.): this figure is arrived at by dividing the "titre" by a factor provided for each batch of Agglutinable Culture.

1 Langer, J. (1907). Verhandl. Ges. Kinderheilk. xxıv. 70.

2 Raymann, G. C. (1920). Journ. Immunol. v. 227.

3 Lewis, J. H. and Wells, H. G. (1922). Journ. Amer. Med. Assoc. Lxxvir. 863.

4 Med. Res. Council (1920). Special Report Series, No. 51. 
The animals were mated thus:

Table I. Matings employed.

\begin{tabular}{cll} 
Group & \multicolumn{1}{c}{ Male } & \multicolumn{1}{c}{ Female } \\
1 & Not immunised & Not immunised \\
2 & Immunised & Not immunised \\
3 & Not immunised & Immunised \\
4 & Immunised & Immunised
\end{tabular}

\section{DATA OF EXPERIMENTS.}

Group 1. (Neither parent immunised.) Before immunisation, in none of the 21 animals used was agglutinin for $B$. typhosus demonstrable in a dilution of serum of 1 in 25 ; similarly, the blood of the three offspring of the normal pair showed no agglutinin.

Group 2. (Male immunised, female not immunised.) The serum of the male showed a titre of 590 s.A.U. At the birth of the young, the maternal serum showed no agglutinin in a dilution of 1 in 25 , nor did the sera of the three offspring, tested immediately, and at intervals of 24 and 48 hours after birth.

- This result agrees with that of the majority of workers, and with Ehrlich's ${ }^{1}$ original finding, that the male cannot transmit acquired immunity.

Group 3. (Male not immunised, female immunised.)

Case 1. At mating the serum of the female contained 280 s.A.u., but towards the end of gestation the titre had fallen to 110 s.A.U. Twelve hours after an intraperitoneal dose of 1.00 c.c. of suspension two young were born, one alive and one dead. Serum was obtained from the former 36 hours after birth, and its stomach content removed.

$\left.\begin{array}{l}\text { Titre of serum of mother }=110 \text { s.A.U. } \\ \text { Titre of serum of young }=290 \text { s.A.U. }\end{array}\right\}$ Tests in duplicate.

The curdled colostrum from the stomach was extracted by grinding with sand and 5.00 c.c. of normal saline solution, spinning, and filtering. The clear fluid which resulted was substituted for serum in a Dreyer series, with suitable controls. No agglutination was demonstrable.

The higher titre of the serum of the offspring might be explained by the ingestion of colostrum rich in agglutinin, and failure to obtain evidence of antibody in the stomach content does not exclude this. In the first place I omitted to adjust the reaction of the colostrum extract; and secondly, Bond ${ }^{2}$ has shown that grinding decreases the haemagglutinin content of the supernatant portion of human milk, although this fractional grinding process may increase the agglutinating capacity of an immune serum for its specific organism. Possibly Bond's findings may have a bearing upon such a result as the above.

Case 2. The female received three doses of 1.00 c.c. suspension, the last a fortnight before term. The two young were killed 18 and 36 hours after

1 Ehrlich, P. (1892). Zeitschr. f. Hyg. xII. 183.

${ }^{2}$ Bond, C. J. (14. vi. 1919). Brit. Med. Journ. I. 
birth, and blood samples and the whole content of the stomachs were obtained.

$$
\begin{aligned}
& \text { Titre of serum of mother }=500+\text { S.A.U. } \\
& \text { Titre of serum of young }(1)=500 \text { S.A.U. } \\
& \text { Titre of serum of young }(2)=500 \text { S.A.U. }
\end{aligned}
$$

The gastric content was treated as in Case 1, with the further precaution that the $p_{\mathrm{H}}$ of the extract was adjusted to that of guinea-pig serum by neutralisation with $N / 100$ sodium hydroxide solution, the process being carried through at once to prevent further action of the gastric juice.

In neither case was any evidence of agglutinin in the colostrum extract obtained. No other food save bran was available for the young, and no bran was recognised in the stomachs.

In order to obtain serum from the young before there was any possibility of their receiving colostrum, they were removed from the tubes of the female near the end of pregnancy. (Under ether anaesthesia a free median incision exposes both tubes. The ovarian arteries are easily identified and clamped, and the tubes opened. Each set of umbilical vessels is then clamped, divided on the placental side, and the foetus withdrawn. After removal of the amnion, and drying to prevent contamination with amniotic fluid, blood may be obtained from the umbilical vessels. If the mother is to be kept alive, the operation must be done under aseptic precautions. The ovarian artery is now included with the stump of the tube in a silk ligature, and the remainder of the tube removed. Catgut is used to suture peritoneum and muscles in one layer, and silk for the skin stitch. This was done in two cases, the animals being afterwards convenient sources of a powerful agglutinating serum; in both recovery was rapid and uneventful.)

Case 3. The female had been immunised before mating, and during gestation received three doses of 1.00 c.c. suspension, the last 48 hours before operation.

$$
\begin{aligned}
& \text { Titre of serum of mother }=590 \text { s.A.U. } \\
& \text { Titre of serum of (three) young }=590 \text { s.A.U. }
\end{aligned}
$$

Case 4. The female had been immunised before mating, and received a dose of 1.00 c.c. suspension intraperitoneally, six hours before operation.

$$
\begin{aligned}
& \text { Titre of serum of mother }=290 \text { s.A.U. } \\
& \text { Titre of serum of (two) young }=290 \text { s.A.U. }
\end{aligned}
$$

Case 5. The female was immunised during the last month of gestation, and received a dose of 1.00 c.c. suspension, six hours before operation.

Titre of serum of mother $\quad=30$ s.A.U.

Titre of serum of (three) young $=18$ s.A.U.

Case 6. The female had received three weekly doses of $1 \cdot 00$ c.c. suspension, the last six hours before operation.

Titre of serum of mother $\quad=120$ S.A.U.

Titre of serum of (three) young $=25$ s.A.U. 
Case 7. A subcutaneous dose of guinea-pig serum having a titre of $1: 3200$ was administered to a female advanced in pregnancy, and previously proved to have no typhoid agglutinin in her serum. The young were born 36 hours later, and samples of maternal and foetal blood obtained before the ingestion of colostrum could occur.

$$
\begin{aligned}
& \text { Titre of serum of mother }=1: 250 \text { (25 s.A.U.) } \\
& \text { Titre of sera of (two) young }=\text { each } 1: 25 \text { (2.5 s.A.U.) }
\end{aligned}
$$

Case 8. (Control.) A single dose of 1.00 c.c. suspension was given to the female six hours before operation.

$$
\begin{aligned}
& \text { Titre of serum of mother }=\text { Nil. } \\
& \text { Titre of serum of (one) young }=\text { Nil. }
\end{aligned}
$$

\section{Group 4. (Both parents immunised.)}

Case 9. Both parents received ten weekly doses of 1.00 c.c. suspension, the last four days before term. Blood was obtained from the (single) young 30 minutes after birth.

Titre of serum of mother $=590$ s.A.U.

Titre of serum of young $=310$ s.A.U.

Table II. Relative amount of agglutinin in maternal and foetal sera of the cases reported.

Case
1
2
3
4
5
6
7
8
9

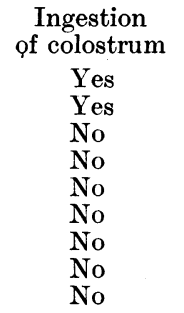

S.A. U. serum
of mother
110
$500+$
$590+$
290
30
120
25
-
590

S.A.U. serum
of young
290
500
590
290
18
25
$2 \cdot 5$
-
310

Type of foetal immunity. In Cases $3,4,5$ and 6 an attempt was made to demonstrate antigen in the foetal blood, the samples being taken 48 hours (Case 3) and six hours (Cases 4, 5 and 6) after its administration to the pregnant

\begin{tabular}{|c|c|c|c|c|c|c|}
\hline Tubes & 1 & 2 & 3 & 4 & 5 & 6 \\
\hline Normal saline (c.c.) & $0 \cdot 30$ & $0 \cdot 30$ & $0 \cdot 30$ & $0 \cdot 30$ & $0 \cdot 30$ & $0 \cdot 30$ \\
\hline Complement (M.H. doses) & 1 & 2 & 3 & 5 & 7 & 10 \\
\hline $\begin{array}{l}\text { Foetal serum, heated for } \frac{1}{2} \mathrm{hr} \text {. } \\
\text { at } 57^{\circ} \text { C. (c.c.) }\end{array}$ & 0.05 & 0.05 & 0.05 & 0.05 & 0.05 & $0 \cdot 05$ \\
\hline & \multicolumn{6}{|c|}{$1 \frac{1}{2}$ hours at $37^{\circ} \mathrm{C}$. } \\
\hline Sensitised ox R.B.C. (c.c.) & $0 \cdot \tilde{50}$ & $0 \cdot 50$ & $0 \cdot 50$ & $0 \cdot 50$ & $0 \cdot 50$ & 0.50 \\
\hline Haemolysis & $\begin{array}{l}\text { Nearly } \\
\text { complete }\end{array}$ & Complete & $\begin{array}{l}1 \frac{1}{2} \text { hour } \\
\text { Complete }\end{array}$ & $\begin{array}{l}\text { at } 37^{\circ} \mathrm{C} \text {. } \\
\text { Complete }\end{array}$ & Complete & Complete \\
\hline
\end{tabular}
animal. Complement fixation tests were carried out with both maternal and foetal sera, as in the following typical experiment.

Minimum haemolytic dose of complement (Guinea-pig) $=0.0125$ c.c. 
In no case was there fixation of complement in either foetal or maternal sera. There are, of course, several possible interpretations of this result; it does not necessarily preclude the presence of antigen in the sera tested.

Agglutinin in the organs. In each case an attempt was made to find out if the amount of agglutinin in the foetal organs varied with the particular organ.

Weighed portions of liver, kidney, and spleen were ground up with sand, in a volume of normal saline solution which was constant for each experiment. The resulting extracts were repeatedly centrifugalised and filtered until clear, and were then used in place of serum in Dreyer series. Similar organ extracts were also prepared from tissue washed in running tap water for 24 hours.

It was hoped that quantitative readings on a basis of weight might be obtained, but the results were very conflicting and unsatisfactory. Dilution for purposes of the test sometimes caused a precipitate in the original extract, for example of kidney; and the temperatures of both incubator $\left(37^{\circ} \mathrm{C}\right.$.) and water bath $\left(57^{\circ} \mathrm{C}\right.$.) caused precipitation of protein substances in the completed preparations. As an example of the inconstant behaviour of these extracts, an experiment may be cited in which a proportion of liver extract was added to the series of both agglutinating and non-agglutinating sera along with emulsion of B. typhosus. Precipitation did not occur in the latter series, although it occurred in the former, and also in controls of extract and saline only. Under such circumstances it was decided that the figures obtained were of no value for comparative purposes.

\section{DISCUSSION.}

It is clear that, as reported by other workers also, antibody may appear in the serum of the offspring of immunised guinea-pigs, without the previous ingestion of colostrum. On the other hand, in animals such as the cow, colostrum may be the sole source of certain at least of the antibodies found in the serum of the young calf. It is probable that the method of transference varies with the dependence of the young upon the dam for their early nourishment, and therefore different methods will be found to predominate in different species.

The origin of the foetal antibody in species independent of the ingestion of colostrum is still doubtful. It may be the result of a foetal reaction to antigen injected into the mother and reaching the foetus by the placenta; or there may be a transference of maternal antibody to the foetus by way of the placenta; or there may be a combination of both factors. It seems established (Case 7) that antibody introduced into the pregnant animal may reach the foetal circulation. With regard to the possibility that antigen molecules may pass through the chorionic villi there is little definite evidence; further, foetal tissues are so lacking in response to the introduction of antigen, that it is difficult to understand how they could show the amount of antibody found in some cases from the mechanism of active immunity alone.

The failure to establish a definite quantitative ratio between the titre of the maternal serum and that of the young-and this is the general experience 
of those who have investigated the subject-would appear to exclude the transference being a physical phenomenon, for were this the case the amounts would be equal in both sera. It is generally accepted that the passage of the chorionic villi by fats and proteins is not a simple physical process such as diffusion, but possibly depends upon the presence of intracellular enzymes in their epithelium. Antigen bodies are of protein nature, and agglutinin is associated with the globulin fraction of the serum. It is therefore probable that transference, whether of antigen or antibody, is the result of cellular activity on the part of the chorionic epithelium. This explanation is not invalidated by any possible proteolytic activity of the intracellular enzymes; agglutinin, as previously stated, resists peptic digestion long enough for it to be absorbed directly from the stomach: indeed, Winterberg ${ }^{1}$, many years ago showed that pepsin had the power of protecting - at least partially - typhoid agglutinin from destruction by hydrochloric acid, even in concentrations in which the acid is found in gastric juice.

The actual type of foetal immunity of this kind must remain for the present undetermined. Experimental observations, and especially those of a quantitative nature, will vary widely with the dependence of the young upon colostrum; with individual peculiarities in the reacting power of the animals; and with the behaviour of the antigens used.

\section{CONCLUSIONS.}

1. Agglutinin for B. typhosus is found in the serum of the young of immunised female guinea-pigs.

2. The agglutinin is present before the ingestion of colostrum.

3. Agglutinin as such may pass through the placenta.

4. The titre of the foetal may equal or exceed that of the maternal serum, but there is no definite quantitative relationship.

5. The complete mechanism of the production of this foetal agglutinin is unknown.

I have gratefully to acknowledge the unfailing interest and encouragement of Prof. D. Noël Paton, in whose laboratory the work was carried out; and advice and technical help from Prof. C. H. Browning, and Dr E. M. Dunlop, Department of Pathology, University of Glasgow.

1 Winterberg, H. (1899). Zeitschr.f. Hyg. xxxII. 375.

MS. received for publication 28. viii. 1923.-ED. 